Vol. XXV No 2019

\title{
A ROMANIAN HEROINE OF BRITISH ORIGIN — MARIA ROSETTI
}

\author{
Gabriela MIHĂILĂ-LICĂ \\ “Nicolae Bălcescu” Land Forces Academy, Sibiu, Romania \\ mihailag2001@yahoo.com
}

\begin{abstract}
The paper analyses the image of Maria Rosetti, the first female journalist in Romania, one of the personalities that played a crucial role for the outcome of the Revolution of 1848, and the way in which she remained in the public consciousness. Born in Guernsey, Scotland, the sister of the diplomat Effingham Grant and wife of the Romanian revolutionary Constantin Alexandru Rosetti "made the cause of Romania her own". Despite being a foreigner, through everything she did, Maria Rosetti tried to help her adoptive country evolve and become a modern unitary state. Besides playing an active role in the escape of her husband and of other revolutionaries arrested by the Turks, she was also the mother of eight children (only four survived) in whom she instilled the most fervent patriotism. Last, but not least, the wife of C. A. Rosetti used her literary talent for pedagogical purposes in order to educate the younger generations according to the desiderata of a new Romanian society. Admired by her contemporaries and by her followers, her portrait was immortalized by C. D. Rosenthal in the famous painting "Revolutionary Romania", becoming a symbol of the love and of the power of sacrifice for her country.
\end{abstract}

\section{Keywords: Maria Rosetti, Revolution, 1848, Romania}

\section{Introduction}

The $19^{\text {th }}$ century represents the period when Romania makes the transition from the simple capitalist cooperation to the industrial mechanization and the European civilization, especially the French one, replaces the Oriental one.

Historian Nicolae Bălcescu wrote that "The Revolution of 1848 was not an irregular, ephemeral phenomenon, without past and future, without any cause other than the random will of a minority or the general European movement. The general Revolution was the occasion and not the cause of the Romanian revolution. Its cause disappears in the days of the centuries. Its planners are eighteen centuries of efforts and sufferance and of work of the Romanian people upon itself" [1]. Most of the people living in the Romanian Principalities, especially the peasants, were discontent with the lack of changes brought by the Revolution of 1821 led by Tudor Vladimirescu. "Even though it had been defeated, it created the premises of structural changes, marked by the Porte's giving up the system of Phanariote rulers Moldavia and Wallachia had been under for more than a century, hoping to hinder the process of liberation of the two countries [2]. Historians speak about an intensification of the exploitation of the peasants and among the boyars there appear contradictory views: some remain conservative, while others adopt liberal, even revolutionary positions.

Just like all the other major events in the history of humankind, the Romanian

DOI: 10.2478/kbo-2019-0096

(C) 2015. This work is licensed under the Creative Commons Attribution-NonCommercial-NoDerivatives 3.0 License. 
Revolution of 1848 revealed men and women that proved outstanding courage and undeniable noble character. According to Dictionary.com, a hero is "a person who, in the opinion of others, has special achievements, abilities, or personal qualities and is regarded as a role model or ideal”. One such person who perfectly fits the definition of a hero is Maria Rosetti [3].

\section{The first years in Romania}

Born in Guernsey, Scotland, in 1819, she was the daughter of Marie Le Lacheur and of Lieutenant Edward Effingham Grant. When her younger brother Effingham Grant became the secretary of the British Consul in Bucharest, Maria was invited to come and stay in Wallachia, a country she had already fallen in love with after having read and listened to her brother's stories about it.

Sabina Cantacuzino, a friend of her family, describes her as: "dark-skinned, not exactly beautiful, but with Mediterranean sex-appeal, expressive, passionate, artistic. (...) She wrote well, with romantic exaltation, she could bring out the beauty in everything she did and she spread it around her. She could decorate a room with only a few items and turn it into such a pleasant sight; she would cut the fabric for a dress while singing and she looked like she was playing: one expected to see it in shreds, but the result would be so stylish and then she would add a little trim to make it absolutely unique [4].

While working as a governess for the children of Col Ion Odobescu, Maria fell in love with Constantin Alexandru Rosetti. Even though he realized that by not marrying Maria he would "lose everything", he hesitated at first due to his financial problems and political duties.

\section{The contribution to the Revolution of 1848}

At first, the marriage, considered a misalliance, was not accepted among the boyars in the capital and the new wife had a hard time trying to integrate herself within the Bucharest society. From the very beginning, Maria tried to learn about the political problems her husband was dealing with and she took part in various meetings and circles were these were debated. She herself held such meetings in her own house. Fearless, Maria Rosetti encouraged the people manifesting against the reactionary boyars by going out in the streets and sharing tricolour cockades, despite having a new born baby and a husband who had been arrested.

When her husband together with other 22 revolutionaries was arrested again and condemned to exile, she did not hesitate to go and try to free them. She sold all her precious belongings, took her several month old baby with her and went to the Ottoman authorities to ask to share the captivity with her husband. The request was denied, but she was allowed to visit the prisoners and to transmit them valuable information about their fate. For more than a month she followed the ships from the shore, with the baby in her arms, helping the arrested men with food, clothes, newspapers and words of encouragement, employing inventive and courageous methods to deceive the jailers. At Svinița the rebels managed to escape with the help of Maria. During these travels she was accompanied by C.D. Rosenthal who later immortalized her in a painting entitled România revoluționară (Revolutionary Romania) that symbolizes the Revolution of 1848. This together with the eulogies brought to her by other contemporaries like Dimitrie Bolintineanu or Jules Michelet contributed to the creation of a legend.

In order to see the real dimensions of her deeds, we should also take into account the fact that during the first half of the $19^{\text {th }}$ century, from a legal point of view, the man was the head of the family. He had the right to beat and imprison his wife who had the statute of a minor. The woman was perceived as the weaker, lesser being who could not even be trusted to educate her children without a man's supervision [5]. 


\section{Exile in France}

During the Rosettis' exile in Paris, Maria managed to remain a permanent moral support for her husband and a loving mother for her children, at the same time making the Romanians' political issues, their history and culture known to the French public. While in France, the two spouses made sure their children were raised as good Romanians and also helped many of those who had left the country albeit they were threatened by poverty.

Only after nine years spent abroad, did the family that now had a lot more members manage to return, again with the direct involvement of Maria Rosetti who had to insist that the authorities issue them the necessary papers.

\section{Peacetime activities}

Unlike the women of the Western world of the $19^{\text {th }}$ century who fought directly for their rights, [6] the women in our country, and Maria Rosetti is no exception, fought first for the ideals of the people they belonged to as well as for humanitarian ones.

Historians are certain that the wife of C.A. Rosetti became familiar with the unionist activity as many of the meetings preparing this movement took place in their house. However, they did not stop her to cater for the needs of all her children. She shared her time between Bucharest, where her husband was doing his political work, Italy, where she went to care for Mircea, and Paris, where Vintilă and Horia were students. Mircea, impressed by her efforts writes in one of his letters that "this mother is only love and devotion, she is capable of any sacrifice, because she seems to believe that her life does not belong to her, but to her children” [7].

Maria realized that a state can not evolve without educating all its people and that is why she became one of the organizers of the management of the central school for girls in Bucharest and wrote articles for Românul and
Românul de duminecă expressing her conviction that a good woman must be a good citizen. She later became the editor of the magazine Mama și copilul, which was meant to educate and to instill in children the pride of being Romanians, at the same time spreading the idea that no nation can be truly free as long as others are in chains.

„Her journalistic writings and her private correspondence illustrate a patriotism verging on exaltation and an honest and total faith in the ideas of liberty, equality and social justice" (Sultana Craia) [8].

We can affirm that through her writings this first Romanian female journalist is one of those that helped the Romanian culture synchronize with the Western one.

In 1871, in her $51^{\text {st }}$ year of life, Maria Rosetti was invited to contribute to the organization of an important patriotic manifestation, which was to take place at Putna, and which was meant to be a homage for the great Romanian voivode Stephen the Great. She, with the help of other women, was to make a decorative cover, this request being another proof of the recognition of her patriotism. The cover was so beautiful that it was exposed in the window of a famous shop in Bucharest.

\section{Contribution to the War of Independence}

During the War of Independence Maria Rosetti worked as a volunteer to raise funds and materials for the front and to establish two hospitals, in Craiova and Turnu Măgurele. People from all over the Romanian territories, from all the strata of society, donated money, things and work convinced that " $<<$ when this good Romanian, this praiseworthy wife will utter her words of comfort at the head of our brother... his pain will be alleviated $>>$ " [9]. She did not spare any effort. She did administrative work, prepared food, took care of and wrote letters for the wounded that called her "Mother Rose". "Mother Rose" did everything with enthusiasm and affability and refused to select her patients on the basis of their rank, stating that she preferred poor soldiers to officers. 
Her own two sons, Horia and Vintilă, had been called from their studies in France by their father to fight for the independence of Romania. From the rich exchange of letters between mother and sons, we are impressed especially by how she urged them to be brave and to bear the hardships of war with dignity. Iosif Vulcan recounted the moment when the Rosettis went to see Vintilă and the military company he was part of when they were about to cross the Danube. The two parents embraced all the soldiers, gave them money, tobacco and treated them as if they were their children [10].

For the activity during the War of Independence, Maria Rosetti was given the diploma of the National Society of the Belgian Red Cross.

\section{The final years}

After the war, her life was marred by several tragedies: the death of Mircea at 32, a fire that destroyed the house she and her family were living in and, probably, the worst of all was the death of her husband. Constantin Rosetti confessed that it was his wife who had made him love life and convinced him to do great deeds so as to be worthy of her love. What impressed those who knew her as well as those who study her life is the dignity that characterized her through all these ordeals. One illustrative example of her dignified behavior is her insistence that her husband eliminate from his will the request for financial help from the government for the paying of their debts.

Maria Rosetti died in 1893. Her sons, obeying her desire, organized her a simple funeral, without any luxury, without invitations. Nevertheless, numerous personalities and simple people from all over the country came to escort her to her final resting place.

\section{Conclusion}

Sabina Cantacuzino, whom we mentioned before, concludes that "through her culture, her virtues, her boundless love for her husband, she was a precious example..." [11]. Nicolae, Bălcescu calls her "the mother of the Revolution”. As a sign of appreciation for what she did for her people and her country, for having risked her life and the safety of her family for the national ideals, Maria Rosetti's name has been given to institutions (School "Maria Rosetti" in Bucharest), to streets (in Bucharest and Craiova), and numerous articles and books have been written by people amazed by her achievements.

\section{References}

[1] Bălcescu, Nicolae, Opere, ediție critic, G. și Elena Zane, Bucresti, 1964, 1974 și 1982, vol. I, II and IV in Berindei, Dan, 1848 in Ţările Române, București, Editura Științifică și Enciclopedică, 1984, p. 7.

[2] Berindei, Dan, Revoluţia română din 1848, București, Editura politică, 1974, p 10

[3] https://www.dictionary.com/browse/hero, 13.02.2019

[4] http://www.istoriibritaniceinBucurești.ro/en/places-and-personalities_doc_15_effinghamgrant-and-maria-rosetti_pg_0.htm, 12.02.2019

[5] Botez, Calypso Corneliu, Problema drepturilor femeii române, Bucureşti, Atelierele grafice Socec \& co., Societate anonimă, 1919

[6] Furet, François, Omul romantic, capitolul „Femeia” de Stephane Michaud, Bucureşti Polirom, 2000

[7] Ioniță, Elisabeta, Maria Rosetti, București, Editura Militară, 1979, p. 50

[8] http://enciclopediaromaniei.ro/wiki/Maria_Rosetti, 12.02.2019

[9] Idem, p. 77

[10] Ibidem, p. 83

[11] Ibidem, p. 8 